\title{
IMPROVEMENT AND POPULARIZATION OF DIVERSIFIED CASSAVA PRODUCTS FOR INCOME GENERATION AND FOOD SECURITY: A CASE STUDY OF KIBABU
}

\author{
H.S. Laswai ${ }^{1 *}$, V.C.K. Silayo ${ }^{2}$, J.J. Mpagalile ${ }^{1}$ and W.R. Balegu ${ }^{1}$ and J. John ${ }^{1}$
}

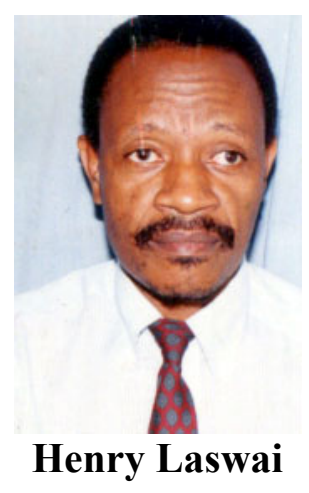

\footnotetext{
${ }^{1}$ Department of Food Science and Technology, Sokoine University of Agriculture,

P.O. Box 3006, Chuo Kikuu, MOROGORO, Tanzania Mobile O744-572646, Tel./Fax 023-2604402

*Corresponding author Email: hslaswai@yahoo.co.uk

${ }^{2}$ Department of Agricultural Engineering and Land Planning,

Sokoine University of Agriculture,

P. O. Box 3003, Chuo Kikuu, MOROGORO, Tanzania.
} 


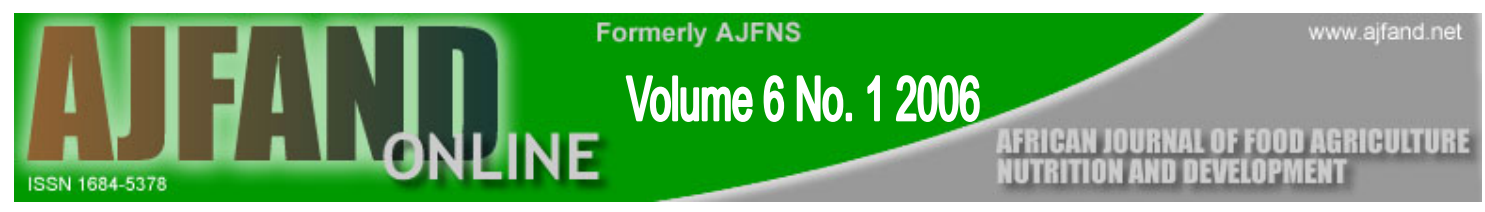

\section{ABSTRACT}

Kibabu is a traditional, plain, deep fried cassava product prepared from cassava paste. It was noticed in Muheza district, Tanzania, to be nutrient-deficient as it was prepared from plain cassava that was only mixed with onions, and then deep fried. There was also room to improve its acceptability for wider dissemination. A study was conducted to improve nutrient content and palatability of traditional kibabu, using $80 \%$ cassava and other staple mixture and $20 \%$ onion-garlic (flavour improver). Laboratory analysis and sensory evaluation were conducted on kibabu from each of the formulations. Results showed that use of groundnuts and soybeans improved the nutritive value. Incorporation of coconut in the formulation improved palatability of kibabu significantly $(\mathrm{P}<0.05)$. Plain cassava kibabu was poor in nutrients and rich in energy but once blended with groundnuts or soybean, the nutrient content improved greatly. The dry matter of the formulated product ranged from 70.36 to $90.34 \%$. On dry weight basis, the nutrient content was as follows: crude protein, 1.21-19.69\%; fat, $6.74-41.51 \%$ and ash content, 1.96 $12.45 \%$. The fibre content ranged from $5.46-25.85 \%$, with coconut contributing most to this increase. The improvement resulting from blending with coconut was not outstanding except for fat and protein but palatability improved significantly ( $P$ $<\mathbf{0 . 0 5}$ ). Incorporation of high levels of soybean in the formulation, although it increased the protein content greatly, it introduced the bean flavour that significantly lowered $(\mathrm{P}<0.05)$ the acceptability of the resulting kibabu. Being a food security crop that could benefit many households in the country, both as food and income source, diversification of uses of cassava is essential. There is therefore, need to promote these paste products for use as snack foods for adults and children, and for income generation. However, care should be taken on nutrient status if kibabu is intended for child feeding. Popularization and promotion work need to target areas that use cassava within and outside the study districts.

Key Words: Cassava, paste products, kibabu, acceptability

French

Amélioration et vulgarisation des produits diversifiés du manioc en vue d'une génération de revenus et de la sécurité alimentaire: Une étude de cas du Kibabu

\section{RÉSUMÉ}

Kibabu est un produit du manioc traditionnel, simple, frit, préparé à partir de la pâte de manioc. Il a été prouvé dans le district de Muheza en Tanzanie que cet aliment est pauvre en nutriments étant donné qu'il est préparé à partir du manioc simple qui n'a été mélangé qu'avec des oignons avant d'être frit. Il faudrait l'enrichir pour qu'il soit davantage accepté et vulgarisé. Une étude a été menée en vue d'augmenter la teneur

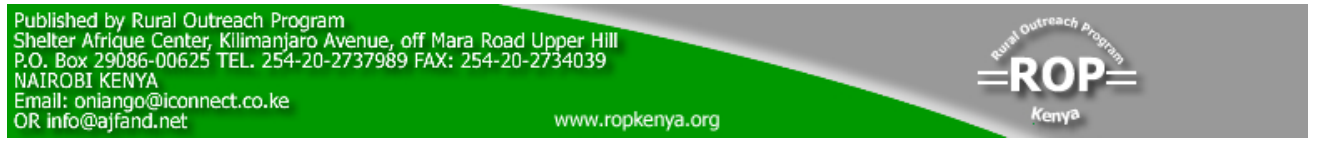




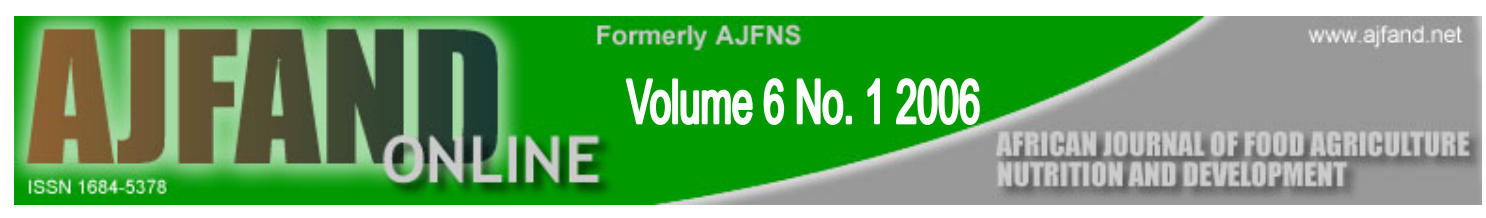

en nutriments et la palatabilité du kibabu traditionnel, en utilisant $80 \%$ de manioc et un mélange d'un autre aliment de base et $20 \%$ d'oignon-ail (substances qui améliorent la saveur). Une analyse de laboratoire et une évaluation sensorielle ont été menées sur le kibabu à partir de chacune des formulations. Les résultats ont montré que l'utilisation des arachides et de soja a amélioré la valeur nutritive. L'incorporation des noix de coco dans la formulation a amélioré considérablement la palatabilité du kibabu $(P<0,05)$. Le kibabu provenant du manioc seul était pauvre en nutriments et riche en énergie, mais une fois qu'il est mélangé avec des arachides ou du soja la teneur en nutriments a augmenté sensiblement. Les matières sèches du produit formulé se classaient entre 70,36 et 90,34\%. A partir du poids sec, la teneur en nutriments s'est présentée comme suit: les protéines brutes 1,21-19,69\%; graisses 6,74 - 41,51 \% et la teneur en cendres 1,96 - 12,45\%. La teneur en fibres se situait entre 5,46 - 25,85 \%, la noix de coco contribuant le plus à cette augmentation. L'amélioration découlant du mélange de la noix de coco n'était pas remarquable, à l'exception des graisses et des protéines, mais la palatabilité s'est améliorée considérablement $(P<0,05)$. Non seulement l'incorporation de niveaux élevés de soja dans la formulation a augmenté énormément la teneur en protéines, mais elle a également introduit une saveur de graine qui a sensiblement baissé $(P<0,05)$ l'acceptabilité du kibabu qui en a résulté. Le kibabu étant un aliment présentant une sécurité alimentaire qui pourrait bénéficier à de nombreux ménages dans le pays, aussi bien en tant qu'aliment qu'en tant que source de revenus, la diversification des utilisations est essentielle. Il faut donc promouvoir ces produits en pâte pour qu'ils soient utilisés comme casse-croûte pour les adultes et pour les enfants et aussi pour la génération de revenus. Néanmoins, il faudrait faire attention à la teneur en nutriment si le kibabu est destiné à l'alimentation des enfants. Il faut que le travail de vulgarisation et de promotion cible les domaines qui utilisent le manioc dans et en dehors des districts qui ont fait l'objet de cette étude.

Mots-clés: manioc, produits en pâte, kibabu, acceptabilité

\section{INTRODUCTION}

Cassava is an important food crop for developing countries, being the main source of energy for between 200 and 300 million people [1]. In Tanzania, cassava is an important subsistence food crop, although it is still considered by many people outside the production areas as a famine reserve crop when cereals, especially maize, fail. Around 84 $\%$ of total production in the country is utilized as human food. The remaining fraction is used for livestock feed, starch making and export [2]. This crop is bulky and highly perishable, but is available all year round thus contributing to food security. Its high energy content helps in minimizing incidences of energy malnutrition [3]. The cyanide problem inherent in the roots can be eliminated by proper processing [4]. Such

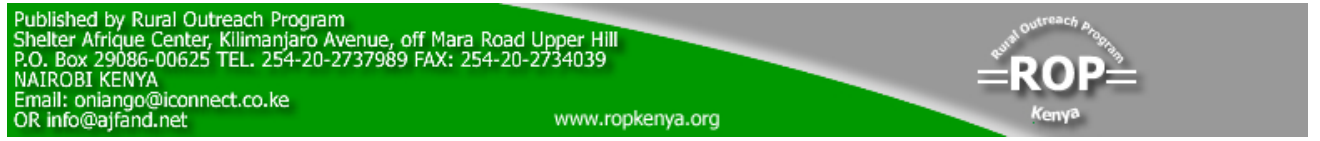




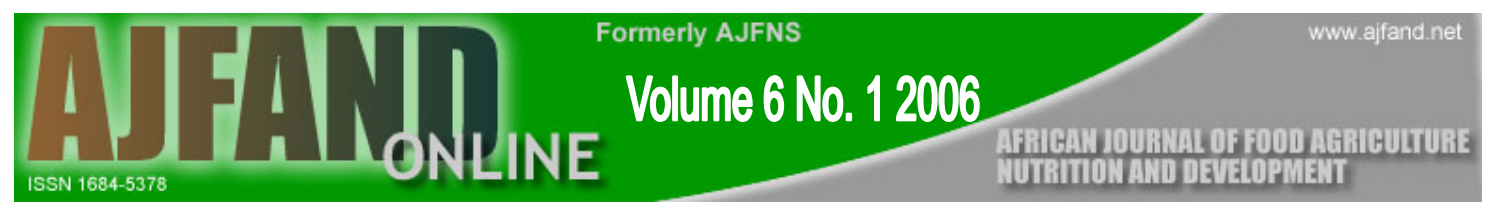

improvement will increase the scope and commercialization, and stimulate production. The Government of Tanzania has long been advised to encourage production and local consumption of cassava, organize the marketing of cassava and promote cassava drying and milling industry for export. Exploitation of various processing methods is often regarded as a means to promote production and enhance food security and commercialization [5].

In Tanzania, processing of cassava for value adding has centred mainly on production of fermented and non-fermented flours for making porridge. Such flours could be blended with cereal flours to improve acceptability of the cassava-based porridges. Exact proportions of these blends have not been fully established. Cassava has also been used in baked products (eg bread) and fried products like doughnuts, buns and chapati (a pan fried unleavened flat round wheat-based product), although not to the extent of the stiff porridges. Another area of utilization of cassava is in the starch industry for food and non-food uses. This product can be obtained from the fresh dried cassava. The easiest form of extraction of this cassava starch is from the fresh cassava using graters to grate the cassava into a fine paste.

Literature on use of cassava as a paste-based product is scanty. Yake yake is one paste product obtained after peeling, washing, grating, drying and sieving the cassava to obtain a meal that is moulded and steam-baked. Agbeli kaklo is a second product encountered in literature resembling yake yake but instead of steam-baking, the meal is mixed with meat, using the hand it is moulded into small cylinders and palm kernel or coconut oil is used for frying [6].

Only one traditional paste product (kibabu) from Muheza district that was encountered in a Participatory Rapid Appraisal (PRA) study [5] could relate to the yake yake and agbeli kaklo. This product looked promising in broadening the food types of cassava for wider transect of the Tanzanian community but needed improvement in processing technology, quality and sensory attributes to improve its acceptability. It was prepared from onions and salt as the only ingredients that were mixed with squeezed cassava paste prior to frying.

The PEM affecting about $50 \%$ of young children in Tanzania, and more than $45 \%$ under-fives suffering from micronutrient deficiency disorders, can be improved by increased consumption of cassava to reduce energy deficiency and soybean to reduce protein and micronutrient deficiencies [17]. Flour is one of the most important cassava products. Steamed paste and wet paste are common in other places but not Tanzania, and so are toasted and steamed granules [8]. If research on cassava is made more effective, perhaps cassava can be used to close the African food gap [9]. The objective of this study was therefore to improve quality and acceptability of this product through studying chemical composition and sensory attributes for purposes of identifying acceptable formulations.

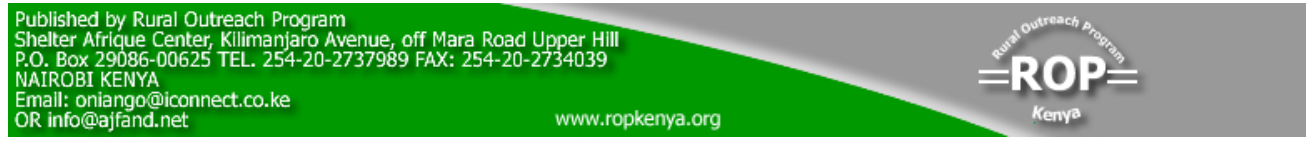




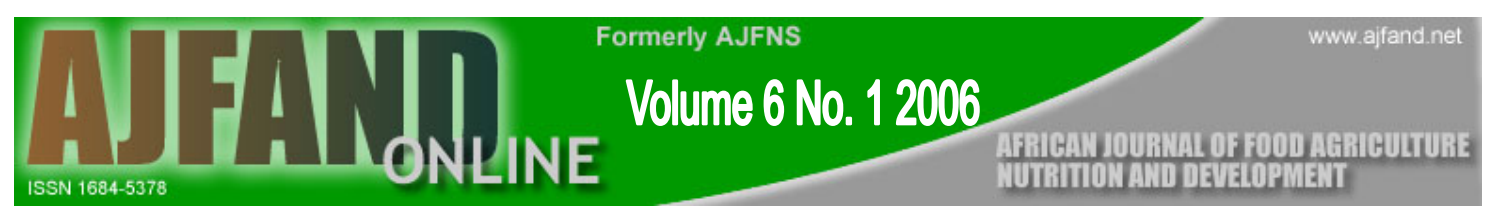

\section{MATERIALS AND METHODS}

\section{Source of raw materials}

The raw materials used in this study included cassava (Kigoma variety), groundnuts, onions, garlic, red pepper and coconut from Morogoro Municipal market. Soybean (Bossier variety), also purchased from the same market, was also included in the study.

\section{METHODS}

\section{Preparation of raw materials}

Cassava roots were peeled, split longitudinally, the mid rib was removed and the remaining cassava grated in a grater (INTERMECH Engineering Ltd). After grating, the paste was squeezed in a polypropylene bag until no more extract came out of the paste. This paste was retained for formulation of kibabu that was done on the same day of squeezing. Then, groundnuts were sorted to remove stones, rotten groundnuts and any chaff. The nuts were roasted and skins removed by rubbing between the hands. Coconut was broken into two halves and using a coconut grater, the flesh was grated and then reserved for use during formulation. Soybean seeds were sorted as for groundnuts washed with water, and then soaked in water $(12 \mathrm{~h})$ with $6 \mathrm{~h}$ changing of soaking water. The soaking water was drained and the soybeans were boiled with water (1:10 for 30 minutes at $100{ }^{\circ} \mathrm{C}$ ). The seeds were then cooled with cold water followed by manual decortication. These were then dried in an oven at $70{ }^{\circ} \mathrm{C}$ until dry. They were then milled in a Bentall (D-200) mill and the flour sieved using a $160 \mathrm{m \mu}$ sieve. The sieved flour was retained until required for formulation. The spices used were onions and garlic. Onions were peeled, washed, cut into very thin slices and retained in airtight container until needed for formulation. Garlic tubers were peeled, grated and stored in airtight containers until needed in the formulation.

\section{Formulation of kibabu}

Details of the formulation of kibabu was as summarized in Table 1.

Preparation of kibabu. This was done as shown in Figure 1. 


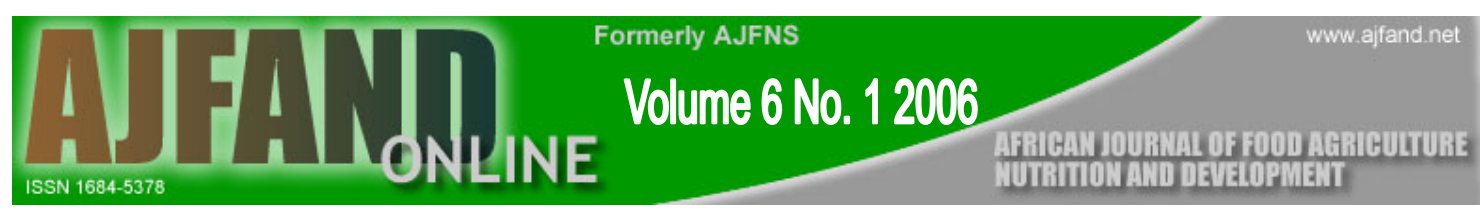

Fresh cassava from field

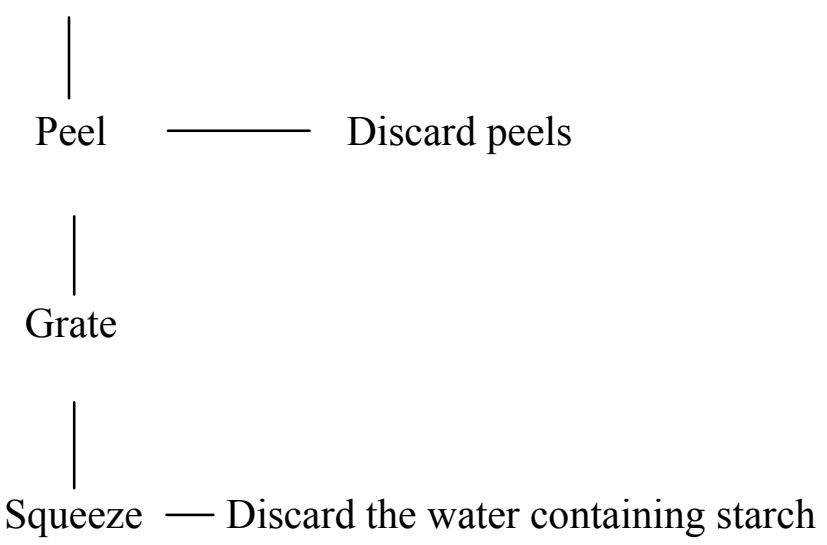

Add sliced or macerated onions or other ingredients
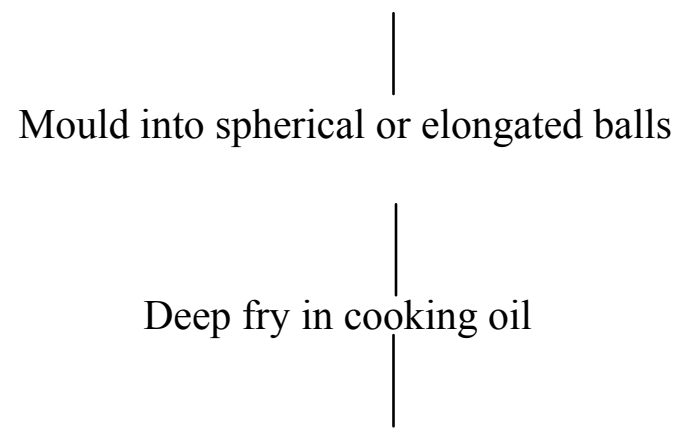

\section{Kibabu}

Figure 1 Flow diagram for production of cassava kibabu

The procedure for preparing the cassava-based kibabu was similar for all formulations. This involved moulding the formulated mixture in the palm, into a cylindrical mould of dimension $2.5 \mathrm{~cm}$ diameter and $7 \mathrm{~cm}$ length. This was then deep fried in boiling cooking oil for 8 - 10 minutes to a nice golden yellow colour, maintaining boiling of the oil throughout the frying. Each formulation was done in triplicate.

\section{Chemical analysis of kibabu samples}

The kibabu samples were subjected to chemical analysis to establish their proximate composition. The samples were analyzed for moisture content, ash, crude protein, crude

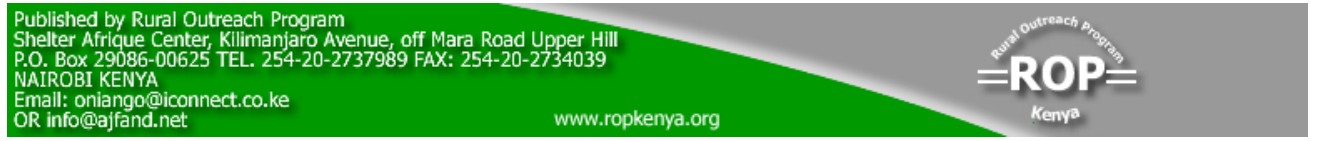




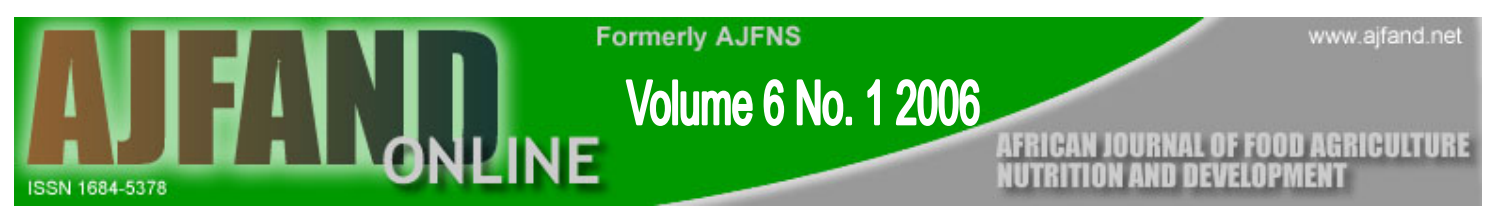

fat, ether extract, crude fibre and carbohydrate content using Official Methods of Analysis [10]. These analyses were conducted in duplicate.

\section{Sensory evaluation of kibabu}

The kibabu samples from different formulations were subjected to sensory evaluation using a 5 point hedonic scale of 1-5, where 1 stood for dislike extremely, 2 dislike moderately, 3 neither like nor dislike, 4 like moderately and 5 like extremely. The data obtained was coded and subjected to statistical analysis using Statistical Package for Social Sciences (SPSS) programme to get the means, which were separated by Duncan's Multiple Range Test for significance at $\mathrm{p}=0.05$.

\section{RESULTS}

\section{Chemical composition}

The proximate analysis of the different kibabu samples prepared in the laboratory, where the ratio of spices used was 3:1, onions:garlic (Table 1), was as summarized in Table 2.

The nutrient content was as follows; crude protein, $1.21-19.69 \%$; fat, $6.74-41.51 \%$ and ash content, $1.96-12.45 \%$. The fibre content ranged from $5.46-25.85 \%$, with coconut contributing most to this increase. The improvement resulting from blending with coconut was not outstanding except for fat and protein but palatability (Table 3) improved significantly $(\mathrm{P}<0.05)$.

\section{Sensory evaluation}

The sensory evaluation results are summarized in Table 3.

Irrespective of formulation, the mean scores of the sensory attributes studied were as follows: taste, 1.80 - 3.63: texture, 2.37 - 3.23; smell, 2.43 - 3.77; colour, 3.00 - 3.77; appearance, $2.73-3.77$ and general acceptability, $1.40-3.37$.

\section{DISCUSSION}

As expected, plain cassava had the lowest fat and protein content. Fibre content was also generally low. The carbohydrate content was highest. Literature shows cassava to consist of mostly carbohydrates and is poor in proteins $[1,3,11]$. In product development, concern should not focus only on the acceptability of the product but should strive to attain nutritional excellence of such a product, through blending with other foods that are nutrient-dense. 


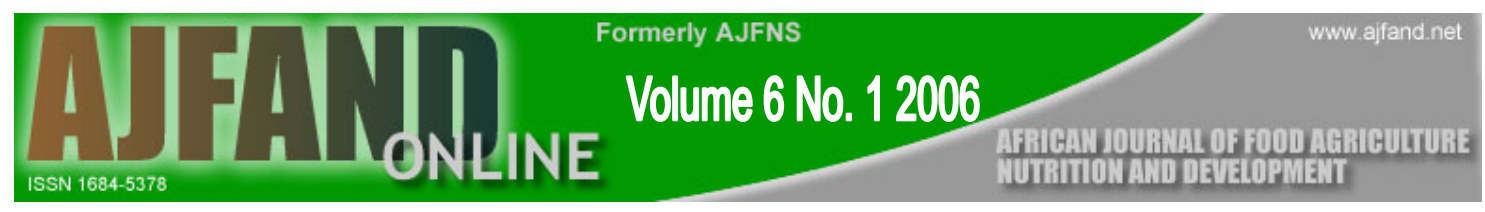

Judging from these laboratory results, there was a limit to which soybean (a promising protein and energy-rich legume) could be used in the blending. For example, as seen from Table 2, it was not possible to increase soybean inclusion to above $40 \%$ of the cassava component that would greatly improve the nutritive value of the product. This was because, despite the nutritional improvement, the binding properties of the cassava would be marginalized, and thus the resulting mixture would not bind properly during frying. This would consequently lead to fragmentation of the final product. Blending with groundnuts or soybean had marked improvement in the crude fibre of cassava blend. Generally, increasing the proportion of legume in the formulation increased the crude fibre, crude protein and crude fat. However, the total carbohydrate content of the blend decreased following this increase in legume in the formulation. Soybean produced the highest content of protein in the blend due to the fact that the protein content of soybean was almost twice that of groundnut. Such products could be potential snack foods for children in localities where cassava is produced and consumed.

As expected, coconut being rich in fat, made the fat content be highest in the coconut formulations. This increased as coconut inclusion was increased in the blends. The increase of fibre in coconut blends resulted from the high fibre content of the coconut flesh. It has been argued that if cassava is processed and sold at primary level, the prospects for cassava as a source of income are still limited, making starch and pellets for animal feed have a lot of prospects [12]. Promotion of kibabu is one other outlet of using cassava in the country, this time as human food. These efforts fully support the recommendation by Balagopalan [12] that wider utilization of cassava can catalyze rural industrial development and raise income for producers, processors and traders and in addition contribute to food security status of its producing and consuming households [12]. Therefore, investment in research and development for diversification is required in order to exploit these markets and may hold some promise for currently marginalized cassava growers.

In Africa, cassava is marketed in five common groups of cassava products. These are fresh roots, dried roots, pasty products (agblima in Ghana, akpu in Nigeria), granulated product (gari in West Africai) and cassava leaves. Tanzanian market is dominated by dried roots $(91 \%)$ and to a lesser extent fresh roots $(6 \%)$. Other products including fresh cassava paste products comprise only $3 \%$ ) [13]. Although more research is needed, cooked cassava paste is a promising food for busy urban consumers and so is the improved kibabu in Tanzania [13].

From Table 3, for the kibabu to be considered acceptable, the mean score for the parameter should at least be 3 . Also, general acceptability encompasses all the parameters and are treated as a true reflection of what the panelist will consider after taking into account all the parameters determining acceptability. Looking at the results, it is evident that taste varied greatly between the formulations. It is logical to promote kibabu

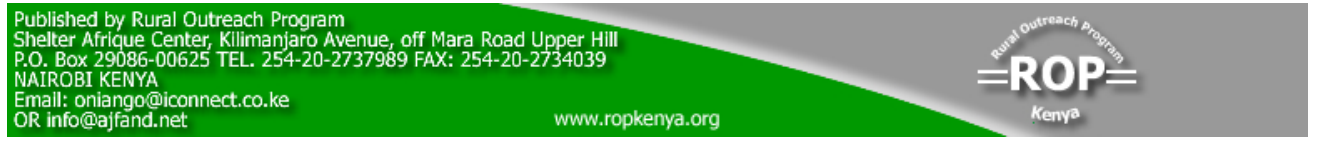




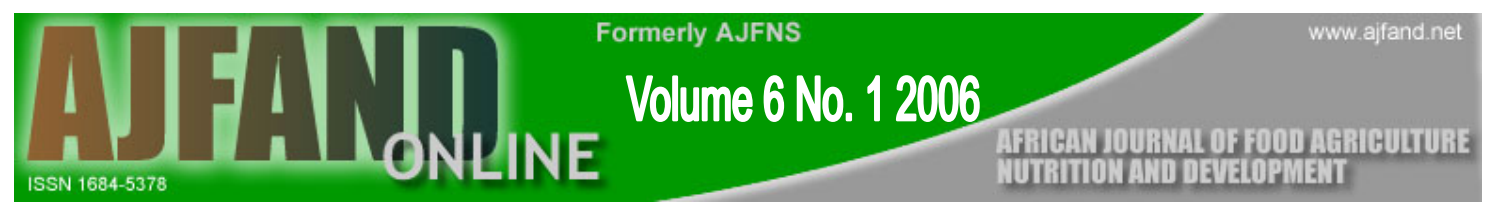

consumption as a means of diversifying cassava-based products - as mentioned earlier [8, $9,14,15]$. Cassava is Africa's second most important food staple after maize, in terms of calories consumed [14]. Nevertheless, it is a marginalized crop in food policy debates because it is burdened with the stigma of being an inferior, low protein food that is uncompetitive with the glamour crops such as imported rice and wheat. Currently, there are deliberate efforts that have succeeded in transforming it from low yielding, famine reserve crop to a high-yielding cash crop [14]. It is moving from a famine reserve, to a rural staple food, to a cash crop for urban consumption, and finally to livestock feed and industrial raw material $[14,15]$. It is thus a promising crop worth more exploitation of its potential.

\section{CONCLUSIONS AND RECOMMENDATIONS}

Results of this study showed a possibility of producing acceptable kibabu by blending with other food staples that could supply the nutrients lacking in cassava and improve the flavour of the product. Such staples include coconut that could significantly improve the fat content, and soybean and groundnut that could improve, in addition to the fat, the protein status. Despite large nutrient content improvement shown by soybean, acceptability could pose a serious challenge. Groundnut used in the roasted grounded form offered promising potential. Disregarding the nutritional inferiority of coconut, acceptability results were high for all formulations used in the study, although the means were not significantly different from that of plain cassava kibabu. This shows that the potential of using coconut to blend with cassava paste to produce acceptable snacks, provided fibre content was not a limiting factor. Blending with soybean or groundnuts - if the resulting blend is acceptable - could be an acceptable snack, especially for children.

The study showed that there is need to promote these paste products as snack for adults and children and income generation. However, care should be taken on nutrient status if kibabu is intended for child feeding. Popularization and promotion work need to target areas that use cassava within and outside the study districts. As a way forward in promoting cassava utilization, new value-added products are needed to develop newer uses of cassava, like kibabu

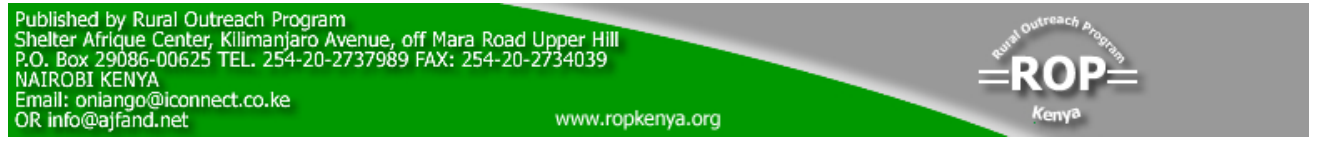




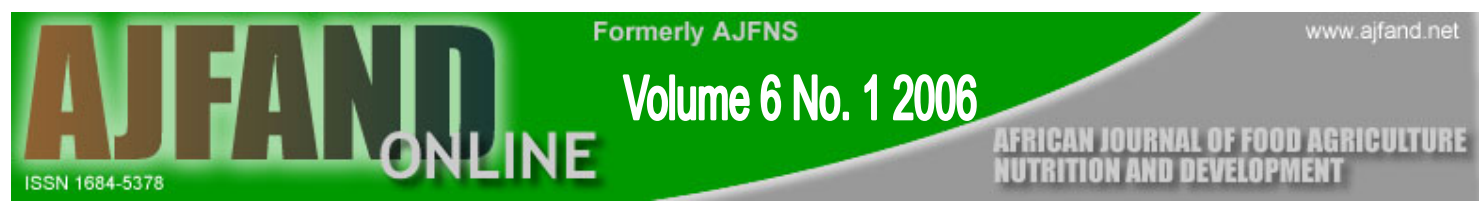

\section{ACKNOWLEDGEMENTS}

The authors greatly acknowledge financial support by TARPII-SUA Research Project funded by the Royal Government of Norway and the United Republic of Tanzania and the panelists for participating in the sensory evaluation work.

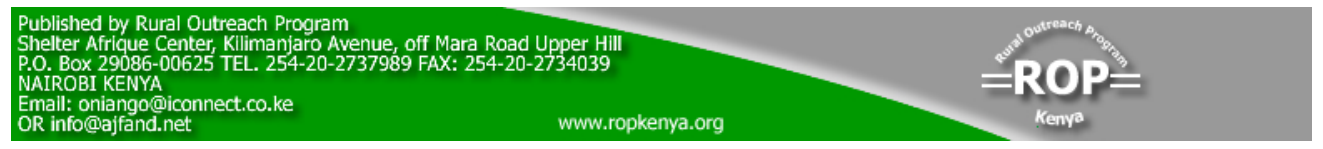




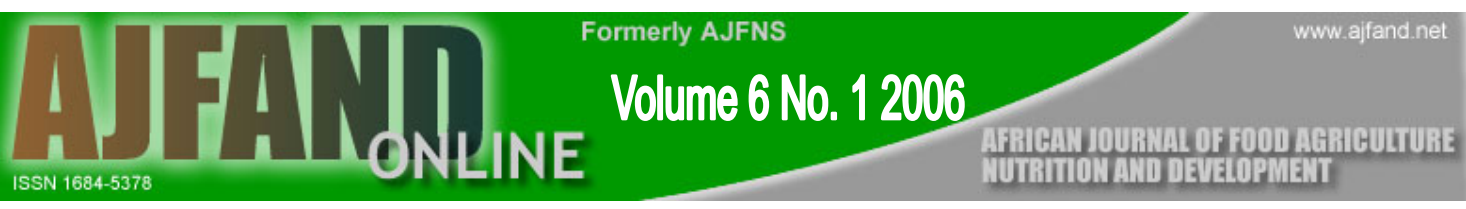

Table 1. Formulations of kibabu using different ingredients

\begin{tabular}{|c|c|c|c|c|}
\hline \multirow[t]{2}{*}{ Sample number } & \multicolumn{4}{|c|}{ Amount of ingredient $(\mathrm{g})$} \\
\hline & Cassava paste & $\begin{array}{l}\text { Ingredie } \\
\mathrm{nt}^{1}\end{array}$ & Onion & Garlic \\
\hline \multicolumn{5}{|c|}{ Groundnut-based kibabu } \\
\hline 628 & 256 & 64 & 60 & 20 \\
\hline 910 & 192 & 128 & 60 & 20 \\
\hline 318 & 128 & 192 & 60 & 20 \\
\hline 274 & 64 & 256 & 60 & 20 \\
\hline \multicolumn{5}{|c|}{ Coconut-based kibabu } \\
\hline 562 & 256 & 64 & 60 & 20 \\
\hline 825 & 192 & 128 & 60 & 20 \\
\hline 251 & 128 & 192 & 60 & 20 \\
\hline 512 & 64 & 256 & 60 & 20 \\
\hline \multicolumn{5}{|c|}{ Soybean-based kibabu } \\
\hline 166 & 256 & 64 & 60 & 20 \\
\hline 327 & 192 & 128 & 60 & 20 \\
\hline 743 & 128 & 192 & 60 & 20 \\
\hline 439 & 64 & 256 & 60 & 20 \\
\hline \multicolumn{5}{|l|}{ Plain kibabu } \\
\hline 256 & 320 & 0 & 60 & 20 \\
\hline
\end{tabular}

${ }^{1}$ The ingredient is groundnut, coconut or soybean depending on formulation 


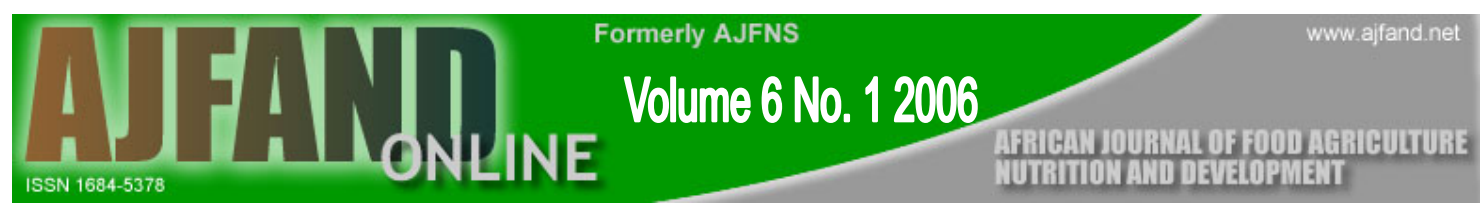

Table 2. Chemical composition of kibabu (dry weight basis)

\begin{tabular}{|c|c|c|c|c|c|c|c|}
\hline Sample & Formulation $^{1}$ & $\begin{array}{l}\text { Moisture } \\
(\%)\end{array}$ & $\begin{array}{l}\text { Ash } \\
(\%)\end{array}$ & $\begin{array}{l}\text { Crude } \\
\text { fibre } \\
(\%)\end{array}$ & $\begin{array}{l}\text { Crude } \\
\text { protein } \\
(\%)\end{array}$ & $\begin{array}{l}\text { Fat } \\
(\%)\end{array}$ & $\begin{array}{l}\text { Carbohyd } \\
\text { rate } \\
(\%)\end{array}$ \\
\hline \multicolumn{8}{|c|}{ Cassava:coconut } \\
\hline 256 & $80: 0$ & 27.01 & 2.37 & 5.46 & 1.21 & 6.74 & 57.22 \\
\hline 562 & $4: 1$ & 25.01 & 2.73 & 18.36 & 2.31 & 21.24 & 30.36 \\
\hline 825 & $3: 2$ & 27.32 & 2.34 & 21.70 & 2.96 & 25.28 & 10.40 \\
\hline 251 & $2: 3$ & 22.86 & 2.57 & 25.05 & 3.91 & 37.05 & 8.57 \\
\hline 512 & $1: 4$ & 11.26 & 1.96 & 25.85 & 5.62 & 36.49 & 28.82 \\
\hline
\end{tabular}

Cassava:soybean

$\begin{array}{llllllll}166 & 4: 1 & 29.64 & 2.78 & 11.00 & 11.63 & 13.51 & 31.44 \\ 327 & 3: 2 & 19.96 & 2.53 & 15.50 & 18.10 & 33.24 & 10.68\end{array}$

Cassava:groundnut

$\begin{array}{llllllll}627 & 4: 1 & 21.45 & 12.45 & 2.85 & 9.10 & 12.36 & 41.79 \\ 910 & 3: 2 & 18.35 & 9.36 & 9.17 & 11.72 & 30.99 & 10.92 \\ 318 & 2: 3 & 15.16 & 3.59 & 20.16 & 16.10 & 38.99 & 6.01 \\ 274 & 1: 4 & 9.61 & 2.96 & 20.69 & 19.69 & 41.51 & 5.54\end{array}$

${ }^{1}$ Formulations missing in the cassava:soybean combinations failed to produce $\boldsymbol{k i b a b u}$ 
Table 3. Mean scores of sensory evaluation results for different formulations of kibabu

\begin{tabular}{|c|c|c|c|c|c|c|}
\hline Sample $^{1}$ & Taste & Texture & Smell & Colour & Appearance & $\begin{array}{l}\text { General } \\
\text { acceptability }\end{array}$ \\
\hline 256 (Cassava) & $2.57 b$ & $2.60 \mathrm{~b}$ & $3.77 \mathrm{a}$ & $3.27 \mathrm{a}$ & $3.67 \mathrm{a}$ & $2.87 \mathrm{a}$ \\
\hline 562 (Cas:Co) & $2.70 \mathrm{~b}$ & $3.00 \mathrm{a}$ & $2.93 b$ & $3.43 \mathrm{a}$ & $3.20 \mathrm{a}$ & $3.17 \mathrm{a}$ \\
\hline 825 (Cas:Co) & $2.90 \mathrm{~b}$ & $3.20 \mathrm{a}$ & $2.83 b$ & $3.40 \mathrm{a}$ & $3.50 \mathrm{a}$ & $3.27 \mathrm{a}$ \\
\hline 251 (Cas::Co) & $3.27 \mathrm{a}$ & $2.90 \mathrm{a}$ & $3.37 \mathrm{a}$ & $3.70 \mathrm{a}$ & $3.60 \mathrm{a}$ & $3.27 \mathrm{a}$ \\
\hline 512 (Cas:Co) & $3.23 \mathrm{a}$ & $3.23 \mathrm{a}$ & $3.17 \mathrm{a}$ & $3.77 \mathrm{a}$ & $3.57 \mathrm{a}$ & $3.30 \mathrm{a}$ \\
\hline 166 (Cas:Soy) & $1.80 \mathrm{~d}$ & $2.37 \mathrm{c}$ & $3.07 \mathrm{~b}$ & $3.30 \mathrm{a}$ & $3.07 \mathrm{a}$ & $1.40 \mathrm{c}$ \\
\hline 327 (Cas:Soy) & $2.03 c$ & $2.60 \mathrm{~b}$ & $2.43 c$ & $3.33 \mathrm{a}$ & $3.77 \mathrm{a}$ & $2.47 \mathrm{~b}$ \\
\hline 629 (Cas:Gnut) & $2.60 \mathrm{~b}$ & $2.77 \mathrm{a}$ & $2.57 \mathrm{c}$ & $3.53 \mathrm{a}$ & $3.50 \mathrm{a}$ & $2.63 b$ \\
\hline 910 (Cas:Gnut) & $3.27 \mathrm{a}$ & $2.83 \mathrm{a}$ & $3.57 \mathrm{a}$ & $3.40 \mathrm{a}$ & $3.10 \mathrm{~b}$ & $3.03 \mathrm{a}$ \\
\hline 318 (Cas:Gnut) & $3.30 \mathrm{a}$ & $3.07 \mathrm{a}$ & $3.00 \mathrm{a}$ & $3.00 \mathrm{~b}$ & $2.83 b$ & $2.90 \mathrm{a}$ \\
\hline 274 (Cas:Gnut) & $3.63 \mathrm{a}$ & $2.83 \mathrm{a}$ & $3.53 \mathrm{a}$ & $3.13 \mathrm{a}$ & $2.73 \mathrm{c}$ & $3.37 \mathrm{a}$ \\
\hline Grand mean & 2.83 & 2.86 & 2.89 & 3.40 & 3.32 & 2.92 \\
\hline \multicolumn{7}{|c|}{$\begin{array}{l}{ }^{1} \text { Cas }=\text { Cassava, } \mathrm{Co}=\text { Coconut, Soy=Soybean and Gnut }=\text { Groundnut. The ratios are as } \\
\text { shown in Table } 1 \\
2 \text { Values in the same column bearing a different superscripts are significantly differen } \\
\text { at }(\mathrm{P}<0.05) \text {. }\end{array}$} \\
\hline
\end{tabular}




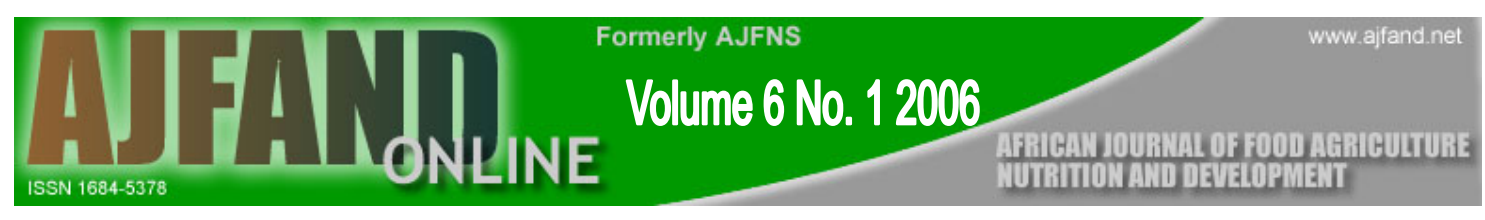

\section{REFERENCES}

1. Gevaudan A, Chuzel G, Didierm $\mathbf{S}$ and $\mathbf{J}$ Andrew Physical properties of cassava mash. Internat. J. Food Sci. Tech. 1989. 24:637-645.

2. http/www.global strategic for cassava development/Africa/Tanzania htm, 2000.

3. Hahn SK, Terry ER, Leuschner K Akobundu IO, Okali C and R Lal Cassava improvement in Africa. Fld Crops Res. 1979. 2:193-226.

4. Essers S Removal of Cyanogens from Cassava Roots: Studies on Domestic Sundrying and Solid-substrate Fermentation in Rural Africa. Ph.D. thesis. Wageningen Agricultural University: The Netherlands. 1995, 131p.

5. Silayo VCK, Laswai HS, Mpagalile JJ, Balegu WR, Mtunda KJ, Chilosa DN, Nyborg ILP and PJ Makungu Development and Promotion of Improved Processing, Packaging and Storage of Sweet Potato and Cassava for Diversification of Use and Commercialization of the Value Added Products Under Smallholder Farmer Conditions. PRA Report for Participating Villages of Songabatini (Muheza), Magindu (Kibaha) and Ihenje (Kilosa). 2001. 67 pp.

6. Doku EV Cassava in Ghana. Faculty of Agriculture, Department of Crop Science, University of Ghana Press:Accra, 1969.

7. Mosha TCE Laswai HS and I Tetens Nutritional composition and micronutrient status of home made and commercial weaning foods consumed in Tanzania. $P l$. Foods Hum. Nutr. 2000; 55:185-2058

8. Nweke FI Processing Potentials for Cassava Production Growth in Africa. $2^{\text {nd }}$ edition, Collaborative Study of Cassava in Africa (COSCA), COSCA Working Paper no. 11, INTEC Printers, Ibadan; 1994.

9. Nweke FI, Kapinga RE, Dixon AGO, Ogwu BO, Ajobo O and CLA Asadu Production Prospects for Cassava in Tanzania. Collaborative Study of Cassava in Africa (COSCA), COSCA Working Paper no. 11, INTEC Printers, Ibadan; 2000.

10. AOAC Official Methods of Analysis. $16^{\text {th }}$ Edn. Association of Official Analytical Chemists, Washington D.C., 1995.

11. CIAT. Cassava: A crop for hard times and modern times, CIAT in Focus Crop commitments. Pp 1-7. http:www.cipotato.org/market/Ars?Ar2001/2health.pdfMicrosoftInternetExplorer. Site visited 23/7/2005.

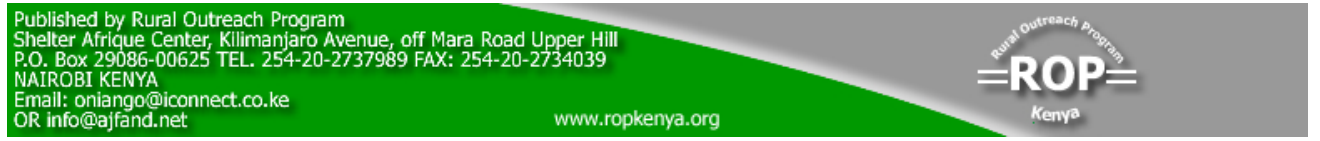


12. Balagopalan C Cassava utilization in Food, Feed and Industry. Chapter 15, pp 301318. In: CAB International 2002. Cassava: Biology, Production and Utilization. R.J. Hillcocks, J.M. Thresh and A.C. Bellotti., 2002.

13. Nweke F New Challenges in Cassava Transformation in Nigeria and Ghana, Environment and Production Technology Division, EPTD Discussion Paper No. 118, International Food Policy Research InstituteWashington, D.C., USA. June 2004.

14. Nweke $\mathbf{F}$ New Challenges in Cassava Transformation in Nigeria and Ghana, InWEnt, IFPRI, NEPAD, CTA Conference "Successes in African Agriculture, Pretoria, December 1-3, 2003.

15. Sanni LO, Oyewole OB, Adebowale AA and K Adebayo Current trends in the utilization of roots and tubers for sustainable development, $2^{\text {nd }}$ International Workshop, Food-based Approaches for a Healthy nutrition, pp 123-138, Ouagadougou, 23-28 November 2003. 